\title{
Association of genetic polymorphisms in the interleukin-10 promoter with risk of prostate cancer in Chinese
}

Jie Liư ${ }^{1 \dagger}$, Bao Song ${ }^{2 \dagger}$, Xueli Bai $^{3}$, Wenjian Liư ${ }^{4}$, Zengjun Li ${ }^{1}$, Jialin Wang ${ }^{2}$, Yan Zheng ${ }^{1}$, Zhehai Wang ${ }^{\text {** }}$

\begin{abstract}
Background: Recent studies identified an increased risk of prostate cancer (PCa) in Caucasian men harboring polymorphisms of genes involved in innate immunity and inflammation. This study was designed to assess whether single nucleotide polymorphisms in the IL-10 promoter play a role in predisposing individuals to PCa in a Chinese population.

Methods: We genotyped three SNPs of the $I L-10$ promoter (-1082A/G, $-819 \mathrm{~T} / \mathrm{C}$ and $-592 \mathrm{~A} / \mathrm{C}$ ) using polymerase chain reaction-restriction fragment length polymorphism analysis in 262 subjects with PCa and 270 age-matched healthy controls. Odds ratio and 95\% confidence interval were determined by logistic regression for the associations between IL-10 genotypes and haplotypes with the risk of PCa and advanced PCa grade.

Results: No significant differences in allele frequency or genotype distribution were observed for any of the IL-10 SNPs between PCa patients and control subjects. Significantly higher frequencies of $-1082 \mathrm{G},-819 \mathrm{C}$ and $-592 \mathrm{C}$ allele and GCC haplotype were observed, however, in early stage patients in comparison to advanced PCa patients (for $-1082 \mathrm{G}, 13.9 \%$ vs $6.1 \%, \mathrm{OR}=2.48, P=0.005$; for $-819 \mathrm{C} 40.3 \%$ vs $30.8 \%, \mathrm{OR}=1.51, P=0.043$; for $-512 \mathrm{C}, 40.3 \%$ vs $30.8 \%, \mathrm{OR}=1.51, P=0.043$; and for haplotype GCC $11.1 \% \mathrm{vs} 5.1 \%, \mathrm{OR}=2.66, \mathrm{P}=0.008$, respectively).

Conclusions: Our results identify that $I L-10$ promoter polymorphisms might not be a risk factor for PCa in Chinese cohorts, but rather incidence of polymorphisms associates with PCa grade, suggesting that IL-10 expression may impact PCa progression.
\end{abstract}

\section{Background}

Prostate cancer $(\mathrm{PCa})$ is among the most common malignant tumors in Western males, ranking second only to lung cancer in cancer mortality [1]. PCa incidence in Asian men is significantly lower, however, the incidence of $\mathrm{PCa}$ in China has increased significantly in recent years [2]. While age, ethnicity, diet, and geographic factors are believed to contribute to the etiology of this disorder [3-5], genetic variations may play a role in susceptibility to PCa [6]. Recent studies suggest that genetic polymorphisms of genes involved in innate immunity and chronic inflammation, including the anti-

\footnotetext{
* Correspondence: wangzhehai64@126.com

+ Contributed equally

'Department of Oncology, Shandong Cancer Hospital \& Institute, Jinan, China

Full list of author information is available at the end of the article
}

inflammatory cytokine Interleukin-10 (IL-10), may impact susceptibility to PCa [6].

IL-10 is produced primarily by macrophages and T lymphocytes. It has important anti-inflammatory and immunosuppressive activities, including the ability to downregulate $\mathrm{T}$ helper 1 (Th1) cytokine and macrophage costimulatory molecule expression. The impact of IL-10 on macrophage function appears to influence blood vessel growth, as reports indicate that IL-10 may contribute to the regulation of angiogenesis in various cancers $[7,8]$. Due to its immunosuppressive and antiinflammatory properties, it has been hypothesized that IL-10 contributes to tumor escape from immune surveillance, thereby enhancing tumor growth. Conversely, animal and in vitro studies demonstrate a correlation between high levels of IL-10 with smaller tumors and reduced metastasis [9].
C Biomed Central

C 2010 Liu et al; licensee BioMed Central Ltd. This is an Open Access article distributed under the terms of the Creative Commons Attribution License (http://creativecommons.org/licenses/by/2.0), which permits unrestricted use, distribution, and reproduction in any medium, provided the original work is properly cited. 
Genetic polymorphisms and inherited factors modulate IL-10 expression. The gene encoding $I L-10$ is located on chromosome 1 (1q31-1q32), and many polymorphisms of the $I L-10$ gene promoter have been described. Examples of polymorphisms include $-1082 \mathrm{~A} /$ $\mathrm{G}$ (rs 1800896), -819 T/C (rs1800871) and -592 A/C (rs1800872) in the proximal region, which influence the transcription of $I L-10 \mathrm{mRNA}$ and the expression of IL10 in vitro [10-12]. In vitro stimulation of peripheral blood lymphocytes using concanavalin A revealed that $I L-10-1082$ GG is associated with a 1.3-fold increase in IL-10 protein production compared to the AA genotype [13]. Similarly, the GCC haplotype exhibits significantly higher transcriptional activity than the ATA haplotype in a luciferase reporter system [14].

Multiple studies have investigated the association between IL-10 expression and incidence of PCa [15-17]. Polymorphisms of the $I L-10$ promoter at -1082 [13-15], -819 or -592 [16] reduce protein expression, and associate with an increased incidence of PCa in some reports [15-18]. In contrast, genetic variation at $-592,-819$, or -1082 or the promoter haplotype ATA resulted in no association in others $[19,20]$. These discrepancies suggest that further investigation of the association of $I L-10$ SNPs with PCa is warranted. Additionally, no such studies have analyzed the impact of these polymorphisms on PCa risk in Chinese patients. Here, we report the association of $I L-10$ polymorphisms with prostate cancer risk in a Chinese population.

\section{Methods}

\section{Study subjects}

The study included 262 newly diagnosed prostate cancer cases (aged 46-83 years) recruited from Shandong Cancer Hospital and Institute, Shandong Provincial Hospital and the Affiliated Hospital of Taishan Medical University between March 2006 and December 2008. The diagnosis of prostate cancer was based on digital rectal examination, serum Prostate specific antigen (PSA) concentration determination and transrectal ultrasound guided prostate biopsy. PSA concentration of $4.0 \mathrm{ng} / \mathrm{mL}$ was considered a cut-off value to carry out diagnostic work-up. Adenocarcinoma of the prostate was pathologically confirmed in all the cases, and the Gleason score (highly differentiated, score 2-5; moderately differentiated, score 6-7; poorly differentiated, score 8-10) was evaluated by pathologists working at each hospital using the Gleason scoring system [21]. The clinical T stage of the patients with PCa was evaluated according to the 2002 TNM staging system for cancer [22]. We defined more aggressive and less aggressive disease based on tumor stage and Gleason score. "Advanced prostate cancer" was defined as either a Gleason score $>7$ or clinical $\mathrm{T}$ stage $>\mathrm{T} 2$.
270 population controls (aged 46 81 years) were accrued from healthy volunteers who visited the three hospitals between July 2006 and July 2008 for general health exams. Controls were screened to ensure that they had never been diagnosed with cancer or other serious disease. The selected controls were matched to the cases by age ( \pm 5 years). Each subject was interviewed for family history of prostate cancer and smoking status. All subjects were unrelated ethnic Han Chinese. Written informed consent was obtained from each participant. The study was approved by the Review Boards of Shandong Cancer Hospital and Institute. Each study participant provided $2 \mathrm{ml}$ peripheral blood sample.

\section{Genotyping}

Genomic DNA was extracted from peripheral blood using Qiagen DNA Isolation Kit (Qiagen GmbH, Hilden, Germany). IL-10 promoter polymorphisms were identified by PCR amplification and restriction analysis (PCR-RFLP; Table 1). Each PCR reaction was performed in a GeneAmp PCR System 9600 thermocycler (Applied Biosystems, Foster, CA) at a final volume of $25 \mu \mathrm{l}$ (containing 5 pmol of each primer, $50 \mathrm{ng}$ genomic DNA, $1.5 \mathrm{mM}$ $\mathrm{MgCl} 2,5 \mathrm{uM}$ dNTPs and $1 \mathrm{U}$ of Taq DNA polymerase in PCR buffer containing $10 \mathrm{mM}$ Tris- $\mathrm{HCl}$ and $50 \mathrm{mM} \mathrm{KCl}$ ). PCR cycles used were as follows: $95^{\circ} \mathrm{C}$ for $5 \mathrm{~min}, 35$ cycles of denaturing at $95^{\circ} \mathrm{C}$ for $40 \mathrm{~s}$, annealing at the indicated temperature for $1 \mathrm{~min}$, extension at $72^{\circ} \mathrm{C}$ for $40 \mathrm{~s}$, and a single final extension at $72^{\circ} \mathrm{C}$ for $10 \mathrm{~min}$. The amplified products were digested with corresponding restriction endonucleases (New England Biolabs, MA, USA), and separated by electrophoresis on a $10 \%$ polyacrylamide gel stained with sliver nitrate for visualization. To confirm the genotyping results, $10 \%$ of PCR-amplified DNA samples were examined by DNA sequencing. Results between PCR and DNA sequencing analysis were $100 \%$ concordant.

\section{Statistical analysis}

The SPSS statistical software package ver.13.0 (SPSS Inc., Chicago, USA) was used for statistical analysis. Demographic data between the study groups were compared by chi-square test and by Student t-test. Each polymorphism was tested for deviation from HardyWeinberg equilibrium by comparing the observed and expected genotype frequencies using the chi-square test. For SNP analyses, genotype and allele frequencies of $I L$ 10 were compared between groups using the chi-sqare test, and odds ratios (OR) and 95\% confidence intervals (CIs) were calculated using unconditional logistic regression with adjustment for age and smoking status. The linkage disequilibrium of the three loci and haplotypes of $I L-10(-1082,-819,-592)$ were conducted using the SHEsis software, from the website http://analysis.bio-x. cn/ (Bio-X Inc., Shanghai, China) [23], which uses a 
Table 1 Primers, restriction enzymes and length of digested fragments of IL-10 promoter polymorphism

\begin{tabular}{|c|c|c|c|c|}
\hline Polymorphism & Primer sequence & Annealing temperature & Restriction enzyme & Allele size \\
\hline \multirow[t]{2}{*}{ IL-10-1082G/A } & 5'-CTCGCTGCA ACCCAACTGGC-3' & $58^{\circ} \mathrm{C}$ & Mnll & A:139 bp \\
\hline & 5'-TCTTACCTATCCCTACTTCC-3' & & & $\mathrm{G}: 106,33 \mathrm{bp}$ \\
\hline \multirow[t]{2}{*}{ IL-10-819C/T } & 5'-TCATTCTATGTGCTGGAGATGG-3' & $59^{\circ} \mathrm{C}$ & Mae III & $\mathrm{C}: 125,84 \mathrm{bp}$ \\
\hline & 5'-TGGGGGAAGTGGGTAAGAGT-3' & & & $\mathrm{T}: 209 \mathrm{bp}$ \\
\hline \multirow[t]{2}{*}{ IL-10-592C/A } & 5'-GTGAGCACTACCTGACTAGC-3' & $58^{\circ} \mathrm{C}$ & Rsal & C:412 bp \\
\hline & 5'-CCTAGGTCACAGTGACGTGG-3' & & & $A: 175,237 \mathrm{bp}$ \\
\hline
\end{tabular}

Full-Precise-Iteration (FPI) algorithm to reconstruct haplotypes. Additionally, the chi-sqare test was used to perform the association of IL-10 allelic and haplotype frequencies and the "advanced grade" among PCa patients. $\mathrm{P}$ values $<0.05$ were considered to be statistically significant.

\section{Results}

\section{Characteristics of PCa patients and controls}

A total of 262 prostate cancer cases and 270 healthy controls were recruited for the present study. All subjects were ethnic Chinese. Table 2 shows the demographic characteristics of the case and control groups. The age distributions and smoking status were similar for cases and controls. The incidence of people with a family history of PCa was higher in the case group than in the control group, however the differences were not significant $(5.3 \%$ vs $2.2 \%, \mathrm{P}=0.067)$. The average PSA level in case patients $128.33 \pm 634.21$ (4.0-4165.0) ng/ml was significantly higher than in controls $2.146 \pm 0.954(0.1 \sim 3.9) \mathrm{ng} / \mathrm{ml}(\mathrm{P}<0.001)$. Among the PCa group, $182(69.5 \%)$ of cases had a high serum PSA level > $10 \mathrm{ng} / \mathrm{ml} ; 161$ (62.5\%) cases were Gleason $>7 ; 156(59.5 \%)$ cases were $>$ T2 stage. According to our

Table 2 Characteristics of PCa patients and controls

\begin{tabular}{|c|c|c|c|}
\hline Characteristics & Patients, $n(\%)(n=262)$ & Controls, $n(\%)(n=270)$ & $\mathbf{P}$ \\
\hline \multicolumn{4}{|l|}{ Age } \\
\hline$<50$ & $8(3.0)$ & $9(3.3)$ & 0.729 \\
\hline $50-59$ & $18(6.9)$ & $20(7.4)$ & \\
\hline $60-69$ & $83(31.7)$ & $86(31.9)$ & \\
\hline $70-79$ & 123(46.9) & $130(48.1)$ & \\
\hline$\geq 80$ & $30(11.5)$ & 25(9.3) & \\
\hline Average age & $70.7 \pm 8.4$ & $70.2 \pm 8.5$ & \\
\hline \multicolumn{4}{|l|}{ Smoking status } \\
\hline Nonsmoking & $102(38.9 \%)$ & $109(40.4 \%)$ & 0.734 \\
\hline smoking & $160(61.1 \%)$ & $161(59.6 \%)$ & \\
\hline \multicolumn{4}{|l|}{ History of prostate cancer } \\
\hline Yes & $14(5.3)$ & $6(2.2)$ & 0.067 \\
\hline No & 248(94.7) & 264(97.8) & \\
\hline \multicolumn{4}{|l|}{ PSA (ng/ml) } \\
\hline Average concentration & $128.33 \pm 634.21$ & $2.146 \pm 0.954$ & $<0.001$ \\
\hline$\leq 10$ & $80(30.5)$ & & \\
\hline$>10$ & $182(69.5)$ & & \\
\hline \multicolumn{4}{|l|}{ Gleason score } \\
\hline$\leq 7$ & $72(27.5)$ & & \\
\hline$>7$ & $161(62.5)$ & & \\
\hline missing & $29(11.0)$ & & \\
\hline \multicolumn{4}{|l|}{ Clinical T Stage } \\
\hline$\leq \mathrm{T} 2$ & $93(35.5)$ & & \\
\hline$>\mathrm{T} 2$ & 156(59.5) & & \\
\hline missing & 13(5.0) & & \\
\hline \multicolumn{4}{|l|}{ Agressive status } \\
\hline Early stage & $72(27.5)$ & & \\
\hline Advanced stage & 180(68.7) & & \\
\hline missing & 10(3.8) & & \\
\hline
\end{tabular}


grading system, there were a higher percentage of "advanced" cases (180) than "early stage" (72 cases) among the PCa patients (68.7\% vs. $27.5 \%)$.

\section{IL-10 gene polymorphisms and PCa}

Table 3 shows the distributions of the genotypes and alleles of the $I L-10$ promoter polymorphisms. The genotype distributions for each SNP were consistent with Hardy-Weinberg equilibrium (HWE). Overall, no significant differences between $\mathrm{PCa}$ and control subjects were observed. Allele analyses revealed $I L-10-1082 \mathrm{G}$ in $8.4 \%$ of PCa subjects, vs. $6.1 \%$ of controls $(P=0.113)$. Similarly, $I L-10-819 \mathrm{C}$ and $-592 \mathrm{C}$ were observed in $33.6 \%$ of PCa subjects vs. $30.7 \%$ of controls $(P=0.309)$. Haplotype analyses were performed, and the 4 possible haplotype (ATA, ACC, GCC, GTA) frequencies are shown in Table 3. Strong Linkage disequilibrium (LD) was observed between -1082 and $-819\left(D^{\prime}=0.892\right)$ and -1082 and $-592\left(D^{\prime}=0.892\right)$. Complete LD was observed between -819 and $-592\left(D^{\prime}=1.0\right)$. Major ATA haplotype accounted for $68.1 \%$ and $64.9 \%$ of these four haplotypes in both of the cases and the controls, respectively. There were no significant differences in the estimated frequencies of these haplotypes between $\mathrm{PCa}$ patients and controls.

\section{Association of IL-10 polymorphisms with $\mathrm{PCa}$ aggressiveness}

We next compared the incidence of $I L-10$ polymorphisms in prostate cancer patients in relation to their advanced status. The frequency of the $\mathrm{G}$ allele -1082 was significantly higher in early stage $\mathrm{PCa}$ patients than in advanced patients (13.9\% vs. $6.1 \%$, respectively; $\mathrm{OR}=2.48,95 \% \mathrm{CI} 1.31 \sim 4.70, \mathrm{P}=0.005)$. At the -819 and -592 sites, the $\mathrm{C}$ and $\mathrm{C}$ alleles were also found more frequently in early stages patients than in advanced PCa patients $(40.3 \%$ vs. $30.8 \%$, OR $=1.51$, $95 \%$ CI 1.01 2.26, P = 0.043; Table 4). Additionally, haplotype analysis showed that the frequency of GCC was higher in early stage patients $(11.1 \%$, OR $=2.66$, $\mathrm{P}=0.008)$ in comparison to advanced $\mathrm{PCa}$ patients (5.0\%). Taken together, these data identify no significant correlation between frequency of $I L-10$ polymorphisms and incidence of $\mathrm{PCa}$, however they did reveal a correlation between frequency of polymorphisms and PCa stage.

Table 3 IL-10 polymorphisms and risk of PCa

\begin{tabular}{|c|c|c|c|c|}
\hline Genotype/Allele/haplotype & Controls n (\%) & PCa n (\%) & $P$ & Adjusted $\mathrm{OR}^{*}(95 \% \mathrm{Cl})$ \\
\hline \multicolumn{5}{|l|}{ Genotype(-1082A/G) } \\
\hline AA & 240(88.9) & $222(84.7)$ & & 1.00 \\
\hline$A G$ & $27(10.0)$ & $36(13.7)$ & 0.141 & $1.50(0.87 \sim 2.57)$ \\
\hline GG & $3(1.1)$ & $4(1.5)$ & 0.520 & $1.68(0.35 \sim 8.17)$ \\
\hline \multicolumn{5}{|l|}{ Allele } \\
\hline A & 507(93.9) & 480(91.6) & & 1.00 \\
\hline G & $33(6.1)$ & $44(8.4)$ & 0.113 & $1.48(0.91 \sim 2.38)$ \\
\hline \multicolumn{5}{|l|}{ Genotype(-819 C/T) } \\
\hline$\pi$ & 132(48.9) & $120(45.9)$ & & 1.00 \\
\hline $\mathrm{TC}$ & $110(40.7)$ & $108(41.2)$ & 0.675 & $1.08(0.75 \sim 1.56)$ \\
\hline CC & $28(10.4)$ & $34(12.9)$ & 0.296 & $1.35(0.77 \sim 2.36)$ \\
\hline \multicolumn{5}{|l|}{ Allele } \\
\hline $\mathrm{T}$ & $374(69.3)$ & $348(66.4)$ & & 1.00 \\
\hline C & 166(30.7) & 176(33.6) & 0.309 & $1.14(0.88 \sim 1.48)$ \\
\hline \multicolumn{5}{|l|}{ Genotype(-592 C/A) } \\
\hline $\mathrm{AA}$ & 132(48.8) & 120(45.9) & & 1.00 \\
\hline$A C$ & 110(40.8) & 108(41.2) & 0.675 & $1.08(0.75 \sim 1.56)$ \\
\hline CC & $28(10.4)$ & $34(12.9)$ & 0.296 & $1.35(0.77 \sim 2.36)$ \\
\hline \multicolumn{5}{|l|}{ Allele } \\
\hline A & $374(69.3)$ & $348(66.4)$ & & 1.00 \\
\hline$C$ & 166(30.7) & 176(33.6) & 0.309 & $1.14(0.88 \sim 1.48)$ \\
\hline \multicolumn{5}{|l|}{ Haplotype } \\
\hline ATA & $368(68.1)$ & $340(64.9)$ & & 1.00 \\
\hline $\mathrm{ACC}$ & 139(25.7) & $140(26.7)$ & 0.551 & $1.13(0.86 \sim 1.47)$ \\
\hline GTA & $6(1.1)$ & $8(1.5)$ & 0.489 & $1.42(0.56 \sim 4.12)$ \\
\hline GCC & $27(5.0)$ & $36(6.9)$ & 0.174 & $1.45(0.86 \sim 2.47)$ \\
\hline
\end{tabular}

$\mathrm{OR}^{*}$, adjusted for age and smoking status 
Table 4 Association of IL-10 polymorphisms with PCa aggressiveness

\begin{tabular}{|c|c|c|c|c|}
\hline Allele/Haplotype & Early stage (72) & Advanced stage (180) & $P$ & OR $(95 \% \mathrm{Cl})$ \\
\hline \multicolumn{5}{|l|}{$-1082 A / G$} \\
\hline A & 124(86.1) & 338(93.9) & & 1.00 \\
\hline G & 20(13.9) & $22(6.1)$ & $0.005^{*}$ & $2.48(1.31 \sim 4.70)$ \\
\hline \multicolumn{5}{|l|}{$-819 \mathrm{C} / \mathrm{T}$} \\
\hline $\mathrm{T}$ & $86(59.7)$ & 249(69.2) & & 1.00 \\
\hline C & $58(40.3)$ & $111(30.8)$ & $0.043^{*}$ & $1.51(1.01 \sim 2.26)$ \\
\hline \multicolumn{5}{|l|}{$-592 \mathrm{C} / \mathrm{A}$} \\
\hline A & $86(59.7)$ & 249(69.2) & & 1.00 \\
\hline$C$ & $58(40.3)$ & 111(30.8) & $0.043^{*}$ & $1.51(1.01 \sim 2.26)$ \\
\hline \multicolumn{5}{|l|}{ Haplotype } \\
\hline ATA & $82(56.9)$ & $245(68.1)$ & & 1.00 \\
\hline ACC & $42(29.2)$ & $93(25.8)$ & 0.184 & $1.35(0.87 \sim 2.10)$ \\
\hline GTA & $4(2.8)$ & $4(1.1)$ & 0.128 & $2.99(0.73 \sim 12.2)$ \\
\hline GCC & $16(11.1)$ & $18(5.0)$ & $0.008^{*}$ & $2.66(1.30 \sim 5.45)$ \\
\hline
\end{tabular}

${ }^{* P}<0.05$.

\section{Discussion}

In the present study, we analyzed the association between 3 SNPs of the $I L-10$ promoter $(-1082 \mathrm{~A} / \mathrm{G}$, $-819 \mathrm{~T} / \mathrm{C}$, and $-592 \mathrm{~A} / \mathrm{C}$ ) with incidence of prostate cancer in a Chinese cohort. No significant differences in allele frequency or genotype distribution for any of the IL-10 SNPs were observed between patients with PCa and control subjects. However, significantly higher frequencies of the $-1082 \mathrm{G},-819 \mathrm{C}$ and $-592 \mathrm{C}$ allele and GCC haplotype were observed in early stage $\mathrm{PCa}$ patients in comparison to advanced PCa patients.

IL-10 is a multifunctional cytokine with both immunosuppressive and anti-angiogenic functions, consequently resulting in both tumor-promoting and tumor-inhibiting properties. Multiple epidemiological studies have investigated the association between the $I L-10$ polymorphisms and the risk of different cancer types. Increased serum and peritumoral IL-10 production have been reported in many malignancies. Results with respect to $\mathrm{PCa}$, however, have been inconsistent. The A allele of $I L-10-1082$ was reported by several groups to be positively associated with incidence of PCa [15-17]. Similarly, the T allele at -819 and A allele at -592 resulting in low IL-10 expression, have been associated with increased PCa risk, specifically in high grade tumors [18]. In contrast, Eder et al [19] or Michaud et al [20] report no correlation between IL-10 expression and PCa risk/status. The cause of these differences remains unclear, however several possibilities exist. Discrepancies may exist due to genetic trait differences, or the existence of distinct $I L-10$ genetic polymorphisms amongst specific populations, ethnicities and geographic regions. Furthermore, cancer is a multi-factorial disease. Individual exposures to various environmental factors in combination with genetic susceptibility may have contributed to these varied results.
We observe that the frequency of the $I L-10-1082 \mathrm{G}$ allele in Chinese is similar to the frequencies observed in healthy Korean [24] and Japanese [25] populations, but significantly lower than those reported for Caucasian populations (where the frequency of $I L-10-1082 \mathrm{G}$ is approximately 0.45$)[18,20]$. Interestingly, the frequency of -1082A (93.9\%) and ATA (68\%) is higher in Chinese populations than in Caucasians, yet the incidence of $\mathrm{PCa}$ in Chinese populations is much lower than what is observed in Caucasians. As the $I L-10-1082 \mathrm{~A}$ allele and haplotype ATA are associated with increased PCa risk in Caucasian populations, the association of these polymorphisms with $\mathrm{PCa}$ appears to be ethnically or geographically regulated. The $-819 \mathrm{~T}$ allele and $-592 \mathrm{~A}$ allele are in complete linkage disequilibrium in the present study. The allele ratio for $-819 \mathrm{~T} /-592 \mathrm{~A}$ is 0.69 , significantly higher than those reported for Caucasians (where the frequency of $-819 \mathrm{~T}$ and $-592 \mathrm{~A}$ are approximately 0.22 to $0.32)[18,20]$. These data further confirm that $I L-10$ alleles vary significantly among ethnic groups, and warrant further investigation.

According to the International Agency for Research on Cancer (IARC), the incidence of prostate cancer in China was $1.1 / 10^{5}$ person years (PY) in 1990 [26] and $1.6 / 10^{5}$ PY in 2002[27]. China has the lowest incidence of prostate cancer in the world, yet the manjority of prostate cancers are not diagnosed until the advanced stages of disease progression. As serum prostate-specific antigen (PSA) screening is the only diagnostic for prostate cancer used in China diagnosis may be greatly enhanced by consideration of genetic background. Several studies have reported that the $I L-10-1082 \mathrm{~A}$ allele and ATA haplotye, minor types in Caucasians but major types in China, were associated with increased PCa risk. These results, which suggest that the incidence of $\mathrm{PCa}$ 
patients in China would be greater, differ from the results of our study described here. Clearly, the association of $I L-10$ SNPs and PCa risk and progression warrant future large-scale investigation throughout multiple ethnic populations.

Here, we analyzed the association between $I L-10$ polymorphisms and PCa risks in a Chinese population. Our study revealed that there is no association between IL-10 SNPs and incidence of PCa, however a significantly higher frequency of $-1082 \mathrm{G},-819 \mathrm{C}$ and $-592 \mathrm{C}$ alleles and GCC haplotype were observed in early stage patients compared to advanced PCa patients. To the best of our knowledge, this study is the first to assess the association of $I L-10$ gene polymorphisms with PCa for the Chinese population. Our results did not support a role for $I L-10$ SNPs in developing PCa, but as IL-10 expression alters according to cancer grade, our data suggest that IL-10 expression may impact prostate cancer progression. While the precise mechanisms by which $I L-10$ polymorphisms may modulate PCa progression remains known, evidence suggests that IL-10 modulates immune function, such as NK cell, T cells, and macrophages activity, which would alter disease progression. Additionally, increasing evidence suggests a role for IL-10 in inhibition of angiogenesis, therefore decreases IL-10 expression would de-repress angiogenic activity and promote cancer progression. Acknowledging the relatively limited sample size and for the low allelic frequencies, further studies are warranted.

\section{Conclusions}

In conclusion, Our results suggest that $I L-10$ promoter polymorphisms might not be a risk factor of $\mathrm{PCa}$ development but may impact PCa progression in Chinese patients.

\section{Acknowledgements}

This paper was supported by Grant number 2004GCG2202152 provided by Department of Science Technology of Shandong Province.

\section{Author details \\ 'Department of Oncology, Shandong Cancer Hospital \& Institute, Jinan, China. ${ }^{2}$ Provincial Key Laboratory of radiation oncology, Shandong Cancer Hospital \& Institute, Jinan, China. ${ }^{3}$ Department of Clinical Laboratory, Shandong Provincial Hospital, Jinan, China. ${ }^{4}$ Department of Oncology, Affiliated Hospital of Taishan Medical University, Taian, China.}

\section{Authors' contributions}

$J L$ and $B S$ performed the statistical analysis and drafted the manuscript. $X L B$ and WJL participated in the design of the study and provided clinical biospecimens. ZJL, JLW and YZ carried out the genotyping. ZHW conceived of the study, participated in its design and coordination and helped to draft the manuscript. All authors read and approved the final manuscript.

\section{Competing interests}

The authors declare that they have no competing interests.

Received: 31 March 2010 Accepted: 24 August 2010

Published: 24 August 2010
References

1. Jemal $A$, Siegel $R$, Ward $E$, Hao $Y, X u$ J, Murray $T$, Thun MJ: Cancer statistics, 2008. CA Cancer J Clin 2008, 58:71-96

2. McCracken M, Olsen M, Chen MS Jr, Jemal A, Thun M, Cokkinides V, Deapen D, Ward E: Cancer incidence, mortality, and associated risk factors among Asian Americans of Chinese, Filipino, Vietnamese, Korean, and Japanese ethnicities. CA Cancer J Clin 2007, 57:190-205.

3. Hamasaki $T$, Inatomi $H$, Katoh T, Ikuyama T, Matsumoto T: Clinical and pathological significance of vitaminD receptor gene polymorphism for prostate cancer which is associated with a higher mortality in Japanese. Endocr J 2001, 48:543-9.

4. Hayes VM, Severi G, Padilla EJ, Eggleton SA, Southey MC, Sutherl RL, Hopper JL, GilesGG : Genetic variants in the vitamin D receptor gene and prostate cancer risk. Cancer Epidemiol Biomarkers Prev 2005, 14:997-9.

5. Habuchi T, Suzuki T, Sasaki R, Wang L, Sato K, Satoh S, Akao T, Tsuchiya N, Shimoda N, Wada Y, Koizumi A, Chihara J, et al: Association of vitaminD receptor gene polymorphism with prostate cancer and benign prostatic hyperplasia in a Japanese population. Cancer Res 2000, 60:305-8.

6. Dennis LK, Lynch CF, Torner JC: Epidemiologic association between prostatitis and prostate cancer. Urology 2002, 60:78-83.

7. Huang S, Ullrich SE, Ber-Eli M: Regulation of tumor growth and metastasis by interleukin-10: the melanoma experience. J Interferon Cytokine Res 1999, 19:697-703.

8. Fortis C, Foppoli M, Gianotti L, Galli L, Citterio G, Consogno G, Gentilini O, Braga M: Increased interleukin-10 serum levels in patients with solid tumors. Cancer Lett 1996, 104:1-5.

9. Stearns ME, Rhim J, Wang M: Interleukin 10 (IL-10) inhibition of primary human prostate cell-induced angiogenesis: IL-10 stimulation of tissue inhibitor of metalloproteinase- 1 and inhibition of matrix metalloproteinase (MMP)-2/MMP-9 secretion. Clin Cancer Res 1999 5:189-96.

10. Kingo K, Ratsep R, Koks S, Karelson M, Silm H, Vasar E: Influence of genetic polymorphisms on interleukin-10 mRNA expression and psoriasis susceptibility. J Dermatol Sci 2005, 37:111-3

11. Turner DM, Williams DM, Sankaran D, Lazarus M, Sinnott PJ, Hutchinson IV: An investigation of polymorphism in the interleukin-10 gene promoter. Eur J Immunogenet 1997, 24:1-8.

12. Gibson AW, Edberg JC, Wu J, Westendorp RG, Huizinga TW, Kimberly RP: Novel single nucleotide polymorphisms in the distal IL-10 promoter affect IL-10 production and enhance the risk of systemic lupus erythematosus. J Immunol 2001, 166:3915-22.

13. Eskdale J, Gallagher G: A polymorphic dinucleotide repeat in the human IL-10 promoter. Immunogenetics 1995, 42:444-5.

14. Crawley E, Kay R, Sillibourne J, Patel P, Hutchinson I, Woo P: Polymorphic haplotypes of the interleukin-10 $5^{\prime}$ flanking region determine variable interleukin-10 transcription and are associated with particular phenotypes of juvenile rheumatoid arthritis. Arthritis and Rheumatism 1999, 42:1101-8.

15. Wang MH, Helzlsouer KJ, Smith MW, Hoffman-Bolton JA, Clipp SL, Grinberg V, De Marzo AM, Isaacs WB, Drake CG, Shugart YY, Platz EA: Association of IL10 and other immune response- and obesity-related genes with prostate cancer in CLUE II. Prostate 2009, 69:874-85.

16. Kesarwani P, Ahirwar DK, Mandhani A, Singh AN, Dalela D, Srivastava AN, Mittal RD: IL-10 -1082 G > A: a risk for prostate cancer but may be protective against progression of prostate cancer in North Indian cohort. World J Urol 2009, 27:389-96.

17. McCarron SL, Edwards S, Evans PR, Gibbs R, Dearnaley DP, Dowe A, Southgate C, Easton DF, Eeles RA, Howell WM: Influence of cytokine gene polymorphisms on the development of prostate cancer. Cancer Res 2002, 62:3369-72.

18. Faupel-Badger JM, Kidd LC, Albanes D, Virtamo J, Woodson K, Tangrea JA: Association of IL-10 polymorphisms with prostate cancer risk and grade of disease. Cancer Causes Control 2008, 19:119-24.

19. Eder T, Mayer R, Langsenlehner U, Renner W, Krippl P, Wascher TC, Pummer K, Kapp KS: Interleukin-10 [ATA] promoter haplotype and prostate cancer risk: a population-based study. Eur J Cancer 2007, 43:472-5.

20. Michaud DS, Daugherty SE, Berndt SI, Platz EA, Yeager M, Crawford ED, Hsing A, Huang WY, Hayes RB: Genetic polymorphisms of interleukin-1B (IL-1B), IL-6, IL-8, and IL-10 and risk of prostate cancer. Cancer Res 2006, 66:4525-30. 
21. Epstein Jl, Allsbrook WC Jr, Amin MB, Egevad LL, ISUP Grading Committee: The 2005 International Society of Urological Pathology (ISUP) Consensus Conference on Gleason Grading of Prostatic Carcinoma. Am J Surg Pathol 2005, 29:1228-42.

22. Sabin LH, Wittekind C: TNM classification of malignant Tumors New York: Wiley-Blackwell Press, 62002.

23. Shi YY, He L: SHEsis, a powerful software platform for analyses of linkage disequilibrium, haplotype construction, and genetic association at polymorphism loci. Cell Research 2005, 15:97-8.

24. Jun TY, Pae CU, Kim KS, Han H, Serretti A: Interleukin-10 gene promoter polymorphism is not associated with schizophrenia in the Korean population. Psychiatry Clin Neurosci 2003, 57:153-9.

25. Ide A, Kawasaki E, Abiru N, Sun F, Takahashi R, Kuwahara H, Fujita N, Kita A, Oshima K, Sakamaki H, Uotani S, Yamasaki H, et al: Genetic association between interleukin-10 gene promoter region polymorphisms and type 1 diabetes age-at-onset. Hum Immunol 2002, 63:690-5.

26. Ferlay J, Bocani GLO: Cancer Incidence and Mortality Worldwide Lyon: IARC Press 1998.

27. Ferlay J, Bray F, Pisani P, Parkin DM: Globocan 2002: cancer incidence, mortality and prevalence worldwide. IARC Cancer-Base No 5, version 2.0 Lyon: IARC Press 2004

\section{Pre-publication history}

The pre-publication history for this paper can be accessed here: http://www.biomedcentral.com/1471-2407/10/456/prepub

doi:10.1186/1471-2407-10-456

Cite this article as: Liu et al: Association of genetic polymorphisms in the interleukin-10 promoter with risk of prostate cancer in Chinese. BMC Cancer 2010 10:456.

\section{Submit your next manuscript to BioMed Central and take full advantage of:}

- Convenient online submission

- Thorough peer review

- No space constraints or color figure charges

- Immediate publication on acceptance

- Inclusion in PubMed, CAS, Scopus and Google Scholar

- Research which is freely available for redistribution

Submit your manuscript at www.biomedcentral.com/submit 